\title{
Now New York steps in
}

The New York State Attorney General's office is considering whether or not to impose controls on recombinant DNA experiments performed in facilities in the State. Colin Norman reports from New York

A windowless hearing room on the 47th floor of New York City's World Trade Center last week provided a somewhat unlikely venue for another round of public hearings on the potential risks and benefits associated with recent advances in genetic engineering. The hearing marks a potentially important development in the long process of regulating recombinant DNA research in the United States, for it is the first time that the matter has been taken up by a state government.

Called by the New York State Attorney General, Louis J. I efkowitz, the hearing was designed to elicit the views of various concerned individuals -mostly scientists who have been in the thick of the debate over the potential hazards of recombinant DNA research for the past two years-on whether New York should impose its own controls on the research and, if so, just how strict those controls should be.

The crux of the discussion was concerned with two closely related issucs. First, whether the guidelines, published by the National Institutes of Health last June to control recombinant DNA experiments which NIH supports, are strict enough to guard against possible public health hazards. And second, whether or not the guidclines should be enforced in New York State by law.

The outcome of the discussions in New York will be closcly watched elsewhere in the United States, for other states are likely to take up the matter at some stage. Already, the City Council of Cambridge, Massachusetts, has imposed a temporary moratorium on a few types of recombinant DNA experiments at Harvard and Massachusetts Institute of Technology, while a special review board, consisting of city residents, is looking into the risks and benefits associated with the research. (The Cambridge moratorium was due to expire on October 7 , but it has quietly been extended until January 7 to allow the board more time to make its recommendations.) And a committee of the City Council in San Diego has also been taking evidence from both supporters and opponents of the rescarch. New York is the first state to consider adopting legal controls, however.

According to one official in the Attorney General's office, a major factor which led New York to look into the matter is the fact that the $\mathrm{NIH}$ guidelines apply only to NIH grantees, and there are no legal sanctions which can be applied if the guidelines are violated. Research supported by industry, and even by other government agencies, is not formally covered. Thus a prime considcration in New York is whether or not the controls should be backed by the force of law and made to apply to all facilities. including industrial laboratories.

Last week's hearings consisted of a parade of about a scorc of witnesses who urged the State government to undertake a variety of measures ranging from doing nothing to banning virtually all recombinant DNA experiments in the statc. The hearings were mostly low-key, punctuated by some fairly gentle questioning by officials in the Attorney General's office. They contrasted rather starkly with the highly charged, emotional nature of the Cambridge City Council's hearings earlier this year.

Leading the call for a moratorium on the research were George Wald of Harvard, Leibe Cavalieri of the SloanKettering Institute, Erwin Chargaff of Columbia University and Jonathan King of Massachusetts Institute of Technology. Cavalieri kicked off with a critique of the guidelines and the way in which they had been developed. arguing that there had been only "token" input from the public, and suggesting that "it is up to society to see that the research effort is directed toward solution of problems, not the creation of new problems". Cavalieri was the only speaker to dwell at length on what he called "the hazards of success", suggesting that so far the discussion of recombinant DNA research has failed to consider the implications of the successful manipulation of the genetics of, for example. crop plants. The result, he said, "would be a change in the intricate balance of our environment, which has taken millions of years to establish".

Wald was the most outspoken critic of the research and the guidelincs, however. He suggested that the recent outbreak of Legionnaires @)1976 Nature Publishing Group
Disease in Philadelphia has provided "a heautiful model" of what a public health problem with recombinant DNA research would be like"unidentifiable and impossible to trace to its source". Wald argued that recombinant DNA research should not be conducted in universities, but it should be isolated in one or two national safety facilities.

As for proponents of the research, the most outspoken was James Watson, Director of the Cold Spring Harbor Laboratory. Watson said that he once told former Presidential candidate Sargent Shriver that the furore over recombinant DNA research is "the most overblown thing to enter the American scene since (President Kennedy) created the fallout shelter". Watson argued he could see no danger in transplanting genes from higher organisms into viruses or bacteria, and he said that he could see little hazard even in transferring genes from viruses known to cause cancer in animals into bacteria. The impact of infection by such organisms would be "negligible" compared with the impact of infection by the viruses themselves, he said, and suggested that "the marginal danger of this thing is a joke compared with other dangers". He suggested that the Attorney General's office could better spend its time looking into the potential health hazards of hair dyes and flame retardants in children's clothing. "What started as an attempt by the scientific community to be responsible takes on the aspects increasingly of a black comedy", Watson stated.

Faced with such widely conflicting viewpoints, the New York Attorney General's office is going to have a tough time deciding whether or not to impose additional controls on researchers in New York. Its decision will, however, be carefully watched in other state capitals.

- Eleanor Lawrence adds from London: The US National Institutes of Health guidelines and the report of the British Williams Committee have now been followed by recommendations for the conduct of in vitro recombinant DNA research by two European organisations, the European Science Foundation (ESF) and the European Molecular Biology Organisation (EMBO).

The ESF makes a number of suggestions. It says national registries of recombinant DNA research, analogous to the Genetic Manipulation Advisory Group proposed for Britain, should be set up in each country. It also suggests that all industrial, university and government laboratories be legally obliged to declare relevant aspects of 